\title{
The Leadership Management of the Principal of Madrasa in Improving Teacher Performance at Madrasah Ibtidaiyah of East Lampung Regency
}

\author{
Cipto Handoko ${ }^{1}$, Nirva Diana ${ }^{2}$, Rifda Elfiah ${ }^{3}$, Guntur Cahaya Kesuma ${ }^{4}$ \\ \{Ciptohandoko25@gmail.com ${ }^{1}$, nirvadiana@radenintan.ac.id ${ }^{2}$, rifdaelfiah@radenintan.ac.id ${ }^{3}$, \\ gunturcahayakesuma@radenintan.ac.id $\left.{ }^{4}\right\}$
}

Universitas Islam Negeri Raden Intan Lampung, Bandar Lampung, Indonesia ${ }^{1}$, Universitas Islam Negeri Raden Intan Lampung, Bandar Lampung, Indonesia ${ }^{2}$, Universitas Islam Negeri Raden Intan Lampung, Bandar Lampung, Indonesia ${ }^{3}$, Universitas Islam Negeri Raden Intan Lampung, Bandar Lampung, Indonesia ${ }^{4}$

\begin{abstract}
One of the factors that heavily influence the improvement of teacher performance at madrasa is leadership management. The pre-surveys conducted at MIM Banarjoyo, MII Sumberrejo, and MI Ma'arif 5 Sekampung of East Lampung Regency in terms of planning, organizing, movement, supervision, and evaluation showed good results. However, the performances of the teachers at the three madrasas were in the moderate category which means that the teachers had not optimally performed their duties and functions. This study was a qualitative study that employed the phenomenological approach. The data collecting techniques employed were observation, interview, and documentation. Based on the results of the study, the principals of the madrasas had performed good leadership management in improving teacher performances through planning, organizing, movement, supervision, and evaluation. It was indicated by the good results of teacher performances at the three madrasas. Thus, the better the leadership management, the better the teacher performances.
\end{abstract}

Keywords: Leadership management, principal of madrasa, teacher performance.

\section{Introduction}

Leadership management at madrasas is one of the most important factors in improving teacher performance. Hari Sudrajat states that the leadership management of madrasas' principals must at least be in line with the main tasks and functions of the principals as the head of education, namely (1) planning in terms of setting the direction of the school as an educational institution by formulating the vision, mission, goals, and achievement strategies, (2) organizing in terms of creating an organizational structure, assigning the staff, and assigning the duties and functions of each staff, (3) mobilizing the staff in terms of motivating them through internal marketing and giving examples of external marketing, (4) supervising in terms of supervising, controlling, and guiding all school staff and residents, (5) evaluating the process and results of education as the basis of education and quality growth, performing problem-solving analytically, systematically, and creatively, and avoiding and overcoming conflicts [1]. 
Furthermore, Supardi explains that teacher performance indicators consist ofthe ability to develop learning plans,the ability to carry out learning, the ability to carry out interpersonal relationships, the ability to evaluate learning outcomes, the ability to carry out enrichment programs, the ability to carry out the remedial program [2].

Based on the surveys conducted by the researchers at the three madrasas, the leadership management at MIM Banarjoyo, MII Sumberrejo, and MI Ma'arif 5 Sekampung was in a good category although certain areas needed to be improved. For instance, the leadership management of the principal of MIM Banarjoyo in evaluating was in the moderate category, the leadership management of the principal of MII Sumberrejo in mobilizing, supervising, and evaluating was in the moderate category, and similarly, the leadership management of the principal of MI Ma'arif 5 Sekampung in mobilizing, supervising, and evaluating was in the moderate category. Based on those problems, efforts are needed to optimally improve teacher performances. Furthermore, how are the management efforts of the principals at the three madrassas through the planning, organizing, mobilizing, supervising, and evaluating to improve teacher performance?

The researchers focused this research on the efforts of the principals of the madrasas in improving teacher performance with the following research sub-focus:

a. The planning of the principals in improving teacher performance at MI Muhammadiyah Banarjoyo, MI Islamiyah Sumberrejo, and MI Ma'arif 5 Sekampung of East Lampung Regency.

b. The organization of the principals in improving teacher performance at MI Muhammadiyah Banarjoyo, MI Islamiyah Sumberrejo, and MI Ma'arif 5 Sekampung of East Lampung Regency.

c. The mobilization of the principals in improving teacher performance at MI Muhammadiyah Banarjoyo, MI Islamiyah Sumberrejo, and MI Ma'arif 5 Sekampung of East Lampung Regency.

d. The supervision of the principals in improving teacher performance at MI Muhammadiyah Banarjoyo, MI Islamiyah Sumberrejo, and MI Ma'arif 5 Sekampung of East Lampung Regency.

e. The evaluation of the principals in improving teacher performance at MI Muhammadiyah Banarjoyo, MI Islamiyah Sumberrejo, and MI Ma'arif 5 Sekampung of East Lampung Regency.

The general formulation of the problem was "How is leadership management of the principals of the madrasas in improving teacher performance at madrasah ibtidaiyah (primary schools) in East Lampung Regency?" the details of the formulation of problems were as follows:

a. How is the planning of the principals in improving teacher performance at MI Muhammadiyah Banarjoyo, MI Islamiyah Sumberrejo, and MI Ma'arif 5 Sekampung of East Lampung Regency?

b. How is the organization of the principals in improving teacher performance at MI Muhammadiyah Banarjoyo, MI Islamiyah Sumberrejo, and MI Ma'arif 5 Sekampung of East Lampung Regency?

c. How is the mobilization of the principals in improving teacher performance at MI Muhammadiyah Banarjoyo, MI Islamiyah Sumberrejo, and MI Ma'arif 5 Sekampung of East Lampung Regency?

d. How is the supervision of the principals in improving teacher performance at MI Muhammadiyah Banarjoyo, MI Islamiyah Sumberrejo, and MI Ma'arif 5 Sekampung of East Lampung Regency? 
e. How is the evaluation of the principals in improving teacher performance at MI Muhammadiyah Banarjoyo, MI Islamiyah Sumberrejo, and MI Ma'arif 5 Sekampung of East Lampung Regency?

The objectives of the study were:

a. To uncover and analyze the planning of the principals in improving teacher performance at MI Muhammadiyah Banarjoyo, MI Islamiyah Sumberrejo, and MI Ma'arif 5 Sekampung of East Lampung Regency.

b. To uncover and analyze the organization of the principals in improving teacher performance at MI Muhammadiyah Banarjoyo, MI Islamiyah Sumberrejo, and MI Ma'arif 5 Sekampung of East Lampung Regency.

c. To uncover and analyze the mobilization done by the principals in improving teacher performance at MI Muhammadiyah Banarjoyo, MI Islamiyah Sumberrejo, and MI Ma'arif 5 Sekampung of East Lampung Regency.

d. To uncover and analyze the supervision of the principals in improving teacher performance at MI Muhammadiyah Banarjoyo, MI Islamiyah Sumberrejo, and MI Ma'arif 5 Sekampung of East Lampung Regency.

To uncover and analyze the evaluations of the principals in improving teacher performance at MI Muhammadiyah Banarjoyo, MI Islamiyah Sumberrejo, and MI Ma'arif 5 Sekampung of East Lampung Regency.

\section{Theoretical Framework}

Susilo Martayo states that management is an effort to determine, interpret, and achieve organizational goals by carrying out the functions of planning, organizing, staffing, directing and leadership, and supervising [3].

The principal of the madrasa, as the manager of the institution, must be able to carry out his function as a manager. The management functions are planning, organizing, implementing, coordinating, directing, supervising, and monitoring [4].

Raiser argues that management is the utilization of physical and human resources through coordinative efforts that can be accomplished by performing the functions of planning, organizing, staffing, directing, and controlling [5].

According to Terry, management is a typical process consisting of planning, organizing, mobilizing, and supervising carried out to set and achieve targets that have been determined through the use of humans and other sources [6]. Syafarudin states that management functions cover the planning, organizing, motivating, supervising, evaluating [7].

Teacher performance is the real quality and quantity of work achieved by teachers in carrying out their duties in line with the given responsibilities by developing the learning programs, implementing the learning, conducting evaluations, and evaluating the evaluations. The teacher performance measurement can be seen from the sense of responsibility in carrying out the tasks, mandates, profession, and moral responsibilities. All of those factors can be seen through the obedience and loyalty in carrying out professional duties inside and outside of the school [8].

Sutomo and Prihatin explain that teachers are managers of teaching and learning activities. They also serve as instructional designers, instructors, and evaluators of learning outcomes as well as supervisors of all teaching and learning activities [9]. 
Sa'ud states that teacher performance in the teaching and learning process consists of at least four competencies, namely (1) planning the teaching and learning process, (2) implementing and managing the teaching and learning process, (3) assessing the progress of the teaching and learning process, and (4) mastering the subject matter[10].

Rachmawati and Daryanto state that the manifestation of teacher performance is the teachers' activities in the learning process in terms of planning the learning, implementing the learning activities, and assessing the learning outcomes. Teacher performance can also be shown from how much the required competencies are met [11].

Therefore, the teacher performance indicators are:
a. Planning
b. Implementing
c. Assessment/evaluating
d. Building a relationship with students
e. Performing enrichment programs
f. Conducting remedial programs

\section{Methods}

This research employed qualitative research with a phenomenological approach. Its purpose is to uncover the phenomena and try to find out the events, opinions, existing issues, and phenomena shown by the objects of research. The data was collected through interviews, observations, and documentation.

\section{Result and Discussion}

It was found out that the principals' leadership management at MI Muhammadiyah Banarjoyo, MI Islamiyah Sumberrejo, and MI Ma'arif 5 Sekampung of East Lampung Regency was in the good category indicated by the results of the performance of the three madrassas. The principals' leadership management in improving teacher performance was done by:

a. Planning by formulating the vision, mission, and objectives of the madrasas then holding annual meetings to discuss madrasas' activity plans, teacher training plans, plans to find donors, preparation of learning tools, budget plans, facilities, and infrastructure maintenance plans as well as the plans to anticipate the opportunities, weaknesses, or threats that will be faced later. The monthly work meeting discusses the principals' supervision plans regarding the teaching and learning methods, tools and media selection, and the teaching equipment and facilities.

b. Organizing by creating effective and efficient organizational structures, compiling details of the duties of each staff, involving the staff in decision making, assigning tasks based on educational background.

c. Mobilizing by providing encouragement, motivation, inspiration, or encouragement so that the awareness and willingness of the teachers could be raised, providing guidance through examples of actions in daily life, performing direction and guidance carried out regularly by providing precise, clear, and firm instructions, providing suggestions, input, and orders to the staffs in carrying out the task, providing adequate facilities for teachers, 
giving awards to teachers who excel in their line of duties, developing the teaching profession through workshop, seminar, and group learning.

d. Supervising the process and the readiness of teachers, supervising and monitoring teachers by providing guidance, imposing sanctions on teachers who violate the rules, creating and maintaining a conducive atmosphere and cooperation between teachers.

e. Evaluating the process and results of education, evaluating teachers' portfolio, performing problem-solving creatively, and avoiding and overcoming conflicts.

\section{Conclusion}

Based on the results of research and data analysis, it can be concluded that the principals' leadership management in improving teacher performance in MI Muhammadiyah Banarjoyo, MI Islamiyah Sumberrejo, and MI Ma'arif 5 Sekampung of East Lampung Regency are as follows:

a. The principals' planning improved the teacher performance at Madrasah Ibtidaiyah in East Lampung Regency by formulating the vision, mission, and objectives of the madrasas, planning annual meetings early in the year, planning monthly work meetings, planning training for teachers, and looking for donors.

b. The principals organized the Madrasah Ibtidaiyah in East Lampung Regency by creating an organizational structure, organizing and involving madrasa staff in decision making, and arranging and assigning tasks according to educational background.

c. The principals mobilized the teacher performance at Madrasah Ibtidaiyah in East Lampung Regency by providing encouragement, motivation, and inspiration through actions. They also provided direction and guidance regularly, suggested, and instructed the teachers in carrying out tasks, provided adequate facilities, and developed the teaching profession through workshops and group learning.

d. The principals supervised the teacher performance at Madrasah Ibtidaiyah in East Lampung Regency by supervising and monitoring the teachers, imposing sanctions on teachers who break the rules, creating and maintaining a conducive atmosphere, and establishing cooperation among teachers.

e. The principals' evaluated the teacher performance at Madrasah Ibtidaiyah in East Lampung Regency by evaluating the process and results of education, teacher portfolios, conducting problem-solving problematically and creatively and avoiding and overcoming conflicts.

It can be concluded that the three madrasas' principals possessed their respective advantages. Firstly, the principal of MIM Banarjoyo improved teacher performance by supervising all the staff and distributing the donation to students and students' savings. Secondly, the principal MII Sumberrejo improved teacher performance by conducting regular guidance and direction. Lastly, the principal of MI Ma'arif 5 improved the teacher's performance by giving a proper appreciation for excellent staff.

\section{References}

[1] H. Sudrajat, Manajemen Peningkatan Mutu Berbasis Sekolah. Bandung: Cipta Cekas Grafika, 2004. 
[2] Supardi, Kinerja Guru. Jakarta: Raja Grafindo Persada, 2013.

[3] S. Martayo, Manajemen Sumber Daya Manusia. Yogyakarta: BPPFE, 1980.

[4] S. Sagala, Manajemen Strategik dalam Peningkatan Mutu Pendidikan, Pembuka Ruang Kreativitas, Inovasi dan Pemberdayaan Potensi Sekolah dalam Sistem Otonomi Sekolah, III. Bandung: Alfabeta, 2009.

[5] C. Reeser, Management: Function and Modern Concepts. Philippines: Scott, Foresmand and Company, 1973.

[6] G. R. Terry, Pinciples of Management. London: Richard D. Irwin, Inc, 1975.

[7] Syafarudin, Manajemen Lembaga Pendidikan Islam. Jakarta: Ciputat Press, 2005.

[8] T. Rusyan, Upaya Meningkatkan Budaya Kinerja Guru. Cianjur: CV. Dinamika Karya Cipta, 2000.

[9] Sutomo a/ac T. Prihatin, Manajemen Sekolah. Semarang: Universitas Negeri Semarang Press, 2000.

[10] S. Syaefudin, Inovasi Pendidikan. Bandung: Alfabeta, 2013.

[11] T. Rachmawati a/ac Daryanto, Penilaian Kinerja Profesi Guru dan Angka Kreditnya. Yogyakarta: Gava Media, 2013. 